\title{
Ceratocystis manginecans associated with a serious wilt disease of two native legume trees in Oman and Pakistan
}

\author{
A. O. Al Adawi ' I Barnes* ' I. A. Khan 'A. M. Al Subhi ' A. A. Al Jahwari ' M. L. \\ Deadman · B. D. Wingfield · M. J. Wingfield
}

A. O. Al Adawi · M. J. Wingfield

Department of Microbiology and Plant Pathology, Forestry and Agricultural Biotechnology Institute (FABI), University of Pretoria, Pretoria 0002, South Africa

*I. Barnes (corresponding author) B. D. Wingfield

Department of Genetics, Forestry and Agricultural Biotechnology Institute (FABI), University of Pretoria, Pretoria 0002, South Africa

e-mail: $\underline{\text { irene.barnes@fabi.up.ac.za }}$

\section{A. Khan}

University of Agriculture, Faisalabad 38040, Pakistan

A. M. Al Subhi `M. L. Deadman

Department of Crop Sciences, P.O. Box 34, Sultan Qaboos University, Al Khod 123, Sultanate of Oman

\section{A. O. Al Adawi ·. A. Al Jahwari}

Ghadafan Agriculture Research Station, Ministry of Agriculture and Fisheries, P. O. Box 204. Sohar, 311, Sultanate of Oman 
Abstract A serious wilt disease has recently been found on Prosopis cineraria (Ghaf) in Oman and on Dalbergia sissoo (Shisham) in Pakistan. Disease symptoms on both these native, leguminous hosts include vascular discolouration and partial or complete wilt of affected trees. A species of Ceratocystis was consistently isolated from symptomatic material. Morphological comparisons and analyses of DNA sequence data of the ITS, $\beta$ tubulin, and EF 1- $\alpha$ gene regions showed that the Ceratocystis isolates obtained from both tree species represent $C$. manginecans. This is the same pathogen that is causing the devastating mango sudden decline disease in Oman and Pakistan. This is also the same pathogen that has been reported causing a wilting disease on Acacia mangium in Indonesia. Cross inoculation with $C$. manginecans isolates from P. cineraria, D. sissoo and mango showed that the fungus can cause disease on all three trees.

Keywords Ceratocystis fimbriata $C$. acaciivora ' cross inoculation ' fungi host jumps ' nonorthologous ITS types

\section{Introduction}

Ceratocystis fimbriata sensu lato Ellis \& Halst represents a well recognized group of cryptic fungal species that cause serious diseases on various agricultural and tree crops (Kile 1993; Roux and Wingfield 2009). The pathogen was first described from sweet potato (Ipomoea batatas) causing tuber black rot (Halsted and Fairchild 1891) and species 
in this complex have subsequently been reported from many agricultural crops worldwide, causing vascular discolouration, wilt, canker and root disease. For example, species in the C. fimbriata s. 1. complex have been reported as serious pathogens causing substantial economic losses in hosts such as Annona squamosa, Citrus spp., Coffea arabica, Colocasia esculenta, Crotalaria juncea, Ficus carica, Punica granatum, Mangifera indica, Eucalyptus spp. and Acacia spp. (Kile 1993; CAB International 2001; Roux and Wingfield 2009).

Ceratocystis fimbriata s. 1. represents a complex of cryptic species that are increasingly being differentiated as additional molecular techniques, and especially DNA sequence comparisons, are applied to the group (Wingfield et al. 1996; Barnes et al. 2003; Engelbrecht and Harrington 2005; Johnson et al. 2005; Van Wyk et al. 2007; Rodas et al. 2008; Van Wyk et al. 2009; Van Wyk et al. 2010). For example, wilt disease of Acacia mearnsii (black wattle) for which the causal agent was first reported as C. fimbriata (Morris et al. 1993) was later recognised as a new species, C. albifundus De Beer, Wingfield \& Morris, based on morphological and DNA sequence comparisons (Wingfield et al. 1996). Subsequently, many additional species have been described in the $C$. fimbriata s. 1. complex including C. pirilliformis Barnes \& M. J. Wingfield isolated from Eucalyptus (Barnes et al. 2003), C. cacaofunesta Engelbrecht \& Harrington infecting cacao and $C$. platani (J. M. Walter) Engelbrecht \& Harrington on plane and sycamore trees (Engelbrecht and Harrington 2005), C. neglecta M. van Wyk, Jol. Roux \& C. Rodas and $C$. fimbriatomima M. van Wyk \& M.J. Wingf. isolated from Eucalyptus sp. (Rodas et al. 2008; Van Wyk et al. 2009), C. colombiana M. van Wyk \& M.J. Wingf. and C. papillata M. van Wyk \& M.J. Wingf. isolated from coffee, cacao and citrus (Van Wyk et al. 2010).

A serious disease of Mango (Mangifera indica), similar to a disease of this tree known as 'seca" (Viegas 1960; Ploetz 2003), was reported in Oman and Pakistan in 1998 
(Malik et al. 2005; Al Adawi et al. 2006). For some years the disease in Oman was thought to be caused by a species in the Botryosphaeriaceae (Al Adawi 2002; Al Adawi et al. 2003) but it was later shown to be caused by a species in the $C$. fimbriata s. 1. complex (Al Adawi et al. 2003; Al Adawi et al. 2006). After the application of DNA sequence and morphological comparisons, the fungus was described as a new species, Ceratocystis manginecans M. van Wyk, A.Al Adawi \& M.J. Wingf. (Van Wyk et al. 2007).

Ceratocystis manginecans has killed many thousands of mango trees in Oman and Pakistan (Kazmi et al. 2005; Al Adawi et al. 2006; Van Wyk et al. 2007). The fungus is closely associated with a wood-boring beetle Hypocryphalus mangiferae (Curculionidae: Scoltyinae) that has been shown to carry it to healthy trees (Al Adawi et al. 2006, Al Adawi et al. 2012). Ceratocystis manginecans has also recently been found in Indonesia where, together with $C$. acaciivora Tarigan \& M. Van Wyk, it is closely associated with the rapid wilt and death of the leguminous plantation tree, Acacia mangium (Tarigan et al. 2011).

Recently, native Prosopis cineraria (locally known as Ghaf) trees in Oman have begun to show symptoms of wilt similar to those seen on mango trees infected with $C$. manginecans. Prosopis cineraria (Leguminosae) is an important desert tree species and is one of the few trees capable of surviving without irrigation in harsh and arid conditions (Brown 1991; 1992). Similarly, in Pakistan, a dramatic wilt disease has been observed on native Dalbergia sissoo (locally known as Shisham) trees since1995 (Kazmi et al. 2005). Dalbergia sissoo, like $P$. cineraria is a legume and is indigenous to Haryana and other parts of India, Pakistan, Nepal and Bangladesh (Tantau et al. 2005). Dalbergia sissoo is a multi-purpose tree that has a valuable timber and it is grown in plantations, alongside canals and roadsides, and to define field boundaries on private land (Khan et al. 2004). 
A Ceratocystis sp. was recently reported associated with P. cinerea and D. sissoo in Oman and Pakistan (Al Adawi et al. 2009, Poussio et al. 2010). The main objective of this study was to identify the species of Ceratocystis responsible for the disease associated with these native trees using morphological and DNA sequence comparisons. Furthermore, host specificity and possible host jumps were considered by conducting reciprocal inoculations on mango (Mangifera indica), $P$. cineraria and D. sissoo trees.

\section{Material and methods}

Sample collection and fungal isolation

During December 2004, samples were collected from $P$. cineraria trees showing symptoms of wilt at Wilayat Sohar in Oman. Symptoms included single branches exhibiting wilt symptoms, dark grey-brown vascular discolouration of affected branches or tree trunks and often wilt of entire trees (Fig. 1a and b). Samples were collected by removing the bark and cutting longitudinal strips (approx. $50 \mathrm{~mm}$ ) from freshly infected xylem with stain. Additional samples were taken during the following two years from different areas all in the vicinity of Sohar.

In May 2006, plantations of D. sissoo in Fasilabad, Shorkot, Chenab Negar and Multan, Pakistan were visited to examine disease symptoms in these areas. Symptoms on the trees included black-grey staining of the xylem tissues leaves first turning brown from the tops to the bottoms of trees, and death of the entire trees (Fig. 1c and d). After removing the bark from trees that had recently wilted, longitudinal strips of discoloured (streaked) vascular tissue were removed for isolation. For both P. cineraria and D. sissoo, 
wood samples were stored in plastic bags and preserved in a refrigerator prior to isolations being made.

Because the vascular discolouration on both $P$. cineraria and D. sissoo was very similar to that observed on mango trees dying as result of infection by $C$. manginecans, it was suspected that a Ceratocystis sp. might be involved causing these symptoms. For this reason, carrot baiting (Moller and De Vay 1968a) was used where discoloured wood was placed between two slices of carrot that had first been treated with streptomycin sulphate $(100 \mathrm{mg} / \mathrm{l})$ and incubated at room temperature to induce fungal sporulation on the carrot slices. In addition, pieces of discoloured wood were placed in moist chambers at room temperature $\left(25^{\circ} \mathrm{C}\right)$ for $7-10$ days to induce sporulation directly on infected tissue.

Single ascospore mass that developed at the apices of ascomata on infected wood or carrot slices were transferred to $2 \%$ malt extract agar (MEA, $20 \mathrm{~g} / \mathrm{l}$ malt, $20 \mathrm{~g} / \mathrm{l}$ agar) (Biolab, Midrand, South Africa) in Petri dishes. These cultures were incubated at $25^{\circ} \mathrm{C}$.

Morphological characterization

The morphological characteristics of the Ceratocystis sp. isolated from P. cineraria and D. sissoo trees were compared with C. manginecans collected from mango trees in Oman and Pakistan (Van Wyk et al. 2007) (Table 1). Two isolates of $C$. manginecans from mango in Oman and Pakistan (CMW13854 and CMW23641), two isolates of Ceratocystis sp. from P. cineraria (CMW17568 and CMW17570) and two from D. sissoo (CMW23623 and CMW23625) were selected for morphological comparisons. Morphological observations of the Ceratocystis isolates were made using fungal structures produced on $2 \%$ MEA plates incubated for 10 days at $25{ }^{\circ} \mathrm{C}$. Samples were prepared by mounting fungal structures on glass slides in lactic acid and observing these under a light microscope. For 
each isolate, 25 measurements were taken for the lengths and widths of the ascomatal bases, necks, ascospores as well as primary and secondary conidia and chlamydospores.

Rates of growth were measured for each representative isolate grown on MEA and incubated in the dark at different temperatures ranging from 5 to $35^{\circ} \mathrm{C}$ at $5{ }^{\circ} \mathrm{C}$ intervals. Diameters of cultures were measured across two perpendicular axes after seven days with five replicate plates at each temperature for each isolate. All the morphological data were analyzed by analysis of variance (ANOVA) and means were compared using Tukey's test. All statistical analyses were performed using SAS version 8 (SAS institute, Cary, NC).

DNA extraction, amplification, sequencing and phylogenetic analyses

Mycelium from 12-day-old cultures grown on $2 \%$ MEA plates was scraped from the surface of cultures, freeze dried for $24 \mathrm{~h}$ and then ground into a fine powder using a Geno Grinder (Glenmills). DNA extraction was performed using a phenol: chloroform (1:1) extraction protocol as described by Barnes et al. (2001). Isolated DNA was cleaned by washing with $70 \%$ ethanol and dried under a vacuum. The isolated DNA was resuspended in $50 \mu \mathrm{l}$ sterile SABAX water with $10 \mu \mathrm{l}$ of RNase A (10 mg/ml, Roche Diagnostics, South Africa) and incubated at $37{ }^{\circ} \mathrm{C}$ for approximately $2 \mathrm{~h}$ to digest any residual RNA. The concentration and purity of the DNA was measured with a NanoDrop ND-1000 spectrophotometer (NanoDrop Technologies, Montchanin, Delaware, U.S.A.). DNA was diluted with deionised sterile water to concentrations of $5-20 \mathrm{ng} / \mu \mathrm{l}$.

Amplification of the ITS1 and ITS2 regions flanking the $5.8 \mathrm{~s}$ ribosomal RNA gene was carried out with universal primers ITS1 and ITS4 (White et al. 1990). Part of the $\beta$ tubulin (BT) gene region was amplified using primers $\beta \mathrm{t} 2 \mathrm{a}$ and $\beta \mathrm{t} 2 \mathrm{~b}$ (Glass and Donaldson $1995)$ and part of the translation elongation factor (TEF-1 $\alpha$ ) gene was amplified using the 
EF1-728F and EF1-986R primer set (Jacobs et al. 2004). PCR reactions were prepared in a total volume of $25 \mu \mathrm{l}$ that included $1.5 \mu \mathrm{l}$ of diluted genomic DNA, $1 \mathrm{U}$ of Taq polymerase (Roche Molecular Biochemicals), $2.5 \mu \mathrm{l}$ of $10 \times$ PCR buffer containing $2.0 \mathrm{mM} \mathrm{MgCl}$, $0.5 \mu \mathrm{l}$ of $10 \mathrm{mM}$ of each primer and $2.5 \mu \mathrm{l}$ of $10 \mathrm{mM}$ of dNTPs. Amplifications were performed in a mastercycler gradient thermal cycler (Eppendorf, Germany) using the following parameters: a 2-min step at $96{ }^{\circ} \mathrm{C}$ followed by ten cycles of $20 \mathrm{~s}$ at $94{ }^{\circ} \mathrm{C}, 40 \mathrm{~s}$ at $55^{\circ} \mathrm{C}$ and $45 \mathrm{~s}$ at $72{ }^{\circ} \mathrm{C}$. The last three temperature intervals were repeated for another 30 cycles with a 5 s increase per cycle for the annealing step at $55^{\circ} \mathrm{C}$, followed by a final elongation step for $10 \mathrm{~min}$ at $72{ }^{\circ} \mathrm{C}$. PCR amplicons were visualized under UV light on 1 $\%$ agarose gels (Roche Diagnostics, Mannheim). PCR amplification products were purified using $6 \%$ Sephadex G-50 columns (1 g Sephadex in $15 \mathrm{ml}$ sterile water, Sigma-Aldrich, Steinheim, Germany). Sequencing reactions were prepared in $10 \mu$ l total volumes containing $2 \mu \mathrm{l}$ purified PCR product, $1 \mu \mathrm{l}$ of $10 \mathrm{mM}$ of the same primers used for the first PCR amplification and $2 \mu 1$ 5x dilution buffer and ABI Prism Big Dye Terminator mix, v.3.1 supplied by the manufacturer (Applied BioSystems Inc., Foster City, California). Sequencing PCR cycles consisted of 25 repetitions at $96^{\circ} \mathrm{C}$ for $10 \mathrm{~s} ; 50{ }^{\circ} \mathrm{C}$ for $4 \mathrm{~s} ; 60^{\circ} \mathrm{C}$ for 4 min. Sequencing reactions were cleaned using Sephadex G-50. Sequences were determined using an ABI PRISM 3100 Autosequencer (Applied BioSystems, Foster City, California, USA). Sequences available in GenBank that were the most similar to the DNA sequences produced in this study and those of recently described species in the $C$. fimbriata s. $l$ complex were used in the data sets for alignments (Table 1).

Sequences were aligned using the programme MEGA version 5 (Tamura et al. 2011) and manually adjusted where necessary. Phylogenetic analyses and most parsimonious trees (MP) for each data set were generated in PAUP v. $4.0 b 10$ (Swofford 2002). All characters were assigned equal weight and gaps were treated as a fifth character 
(new state). The heuristic search with 100 random stepwise additions and tree bisection reconnections (TBR) was employed as the swapping algorithm. Branch support for nodes was obtained by performing 1000 bootstrap replicates of the aligned sequences. For parsimony analysis, metrics that were calculated included tree length (TL), retention index (RI) and consistency index (CI). C. pirilliformis was used as the outgroup taxon and the ingroup was considered to be monophyletic.

The DNA substitution model for data sets representing each gene region was determined by Akaike Information Criterion (AIC) using PAUP4.0b10 and MrModeltest version 2.3 (Nylander 2004). These models were incorporated in Bayesian analyses using the programme MrBayes version 3.1.2 (Ronquist and Huelsenbeck 2003). Four chains of Markov Chain Monte Carlo (MCMC) were concurrently run from a random start for 1 million generations and the trees were sampled every $100^{\text {th }}$ generation. Burn-in values were calculated for each data set using Tracer programme version 1.4 and these values were incorporated in MrBayes to exclude all trees sampled before the stationary phase was reached. Posterior probabilities were calculated from a $50 \%$ majority rule consensus tree constructed from the remaining trees (Rannala and Yang 1996).

Inoculation trials

The first of two inoculation trials was designed to evaluate the pathogenicity of the Ceratocystis sp. from $P$. cineraria and $C$. manginecans on $P$. cineraria seedlings. This trial was conducted using two isolates of $C$. manginecans from mango (CMW13851 and CMW13854) and two isolates (CMW17568 and CMW17570) of the Ceratocystis sp. from $P$. cineraria (Table 1). One-year-old $P$. cineraria plants grown from locally collected seeds in $13 \mathrm{~cm}$ diameter pots containing loamy soil mixed with peat moss were used in this trial. 
The $P$. cineraria plants were wounded with a sterile scalpel by making an 1-shaped incision (10 $\mathrm{mm}$ long) on the stems of the seedlings, approximately $20 \mathrm{~cm}$ above the soil level and inserting a mycelial plug of agar (4 mm diam) into each wound site. Seven $P$. cineraria plants were inoculated with each Ceratocystis isolate and the same number of seedlings was inoculated with a sterile plug of MEA to serve as controls. The plants were arranged in a randomized block design. All inoculated wounds were covered with moistened sterile cotton pads and sealed with Parafilm.

The inoculated plants were kept in a shade house and watered twice a week. After 60 days, the bark tissue of the inoculated seedlings was removed above and below the inoculation site and the lengths of the lesions were measured. To re-isolate the inoculated pathogen, wood samples were taken from the margins of the lesions and plated onto MEA plates or placed between two carrot slices.

In a second inoculation trial, host specificity on mango, $P$. cineraria and $D$. sissoo was tested. Nine-month-old mango plants (Pairi cultivar), one-year-old plants of $P$. cineraria propagated from local Omani seed and ten-month-old D. sissoo plants propagated from seed, were grown in the same potting media as described for the first trial. All plants were kept under shade house conditions and irrigated twice per week. Two weeks prior to inoculation, the plants were transferred to a laboratory with a temperature of 24-26 ${ }^{\circ} \mathrm{C}$ and irrigated twice per week. The height and diameter of each plant was measured at the time of inoculation.

The inoculation was conducted using two isolates (CMW13851 and CMW13854) of C. manginecans from mango, two isolates (CMW17225 and CMW17568) of the Ceratocystis sp. from P. cineraria and two isolates (CMW23623 and CMW23625) of the Ceratocystis sp. from D. sissoo. Inoculum of each isolate was grown on MEA for two weeks and $4 \mathrm{~mm}$ diam. mycelial plugs made using a cork borer were inserted into wounds 
of equivalent size made to remove the bark and expose the cambium on the stems of the plants. Points of inoculation were $10 \mathrm{~cm}$ above the soil level in the case of $P$. cineraria and $D$. sissoo and $10 \mathrm{~cm}$ above the graft union in the case of the mango plants. Each isolate was inoculated into three plants per host and three plants of each host were used as controls, inoculating them in an identical manner with a $4 \mathrm{~mm}$ sterile MEA plug. Lesion lengths on the inoculated plants were measured after 30 days.

Statistical analyses of the results were carried out for the two trials using ANOVA in order to compare lesion lengths between isolates and host types compared in the second inoculation trial. In cases with significant $(P<0.05)$ variation among isolates, Fisher's least significant difference (LSD) test was used to compare means. Statistical analyses of the data were performed using SAS statistical software (version 8.2, SAS Institute, Cary, NC, USA).

\section{Results}

Sample collection and fungal isolation

Isolation from symptomatic xylem tissue on $P$. cineraria and $D$. sissoo using both carrot baiting and moist chambers yielded 14 isolates of a Ceratocystis species (Table 2). The overall percentage of isolation from $P$. cineraria and $D$. sissoo samples from different areas was $46.7 \%$ and $38.9 \%$ respectively. Cultures of the isolates obtained in this study are preserved in the culture collection (CMW) of the Forestry and Agriculture Biotechnology Institute, University of Pretoria, Pretoria, South Africa. 
Morphological characterization

Isolates on MEA from $P$. cineraria and D. sissoo clearly represented a member of the $C$. fimbriata s. 1. complex based on morphological characteristics of both the sexual and asexual structures (Upadhyay 1981; Van Wyk et al. 2007). Ascomata were black with globose bases and long necks. Hat shaped and hyaline ascospores exuded from the apices of the ascomata and globose to oval and olive brown chlamydospores were present. Tubular conidiophores giving rise to hyaline and cylindrical conidia were present (Table $3)$.

All of the morphological characteristics of the isolates examined in this study were similar to those in the descriptions given for $C$. manginecans isolated from diseased mango trees (Van Wyk et al. 2007). Isolates from P. cineraria and D. sissoo produced greyish olive cultures and the shape and colour of the ascomatal bases, primary conidia and secondary condia were similar to those of $C$. manginecans isolated from mango from Pakistan and Oman (Van Wyk et al. 2007) (Table 3). There were no significant differences in the dimensions of the structures in the isolates from $P$. cineraria and $D$. sissoo and $C$. manginecans for the ascomatal bases, ascospores and chlamydospores. Variation was observed in the lengths of the ascomatal necks for isolates from all hosts, but they were still within the ranges reported for $C$. manginecans (Van Wyk et al. 2007). The lengths and widths of the primary and secondary conidia overlapped between the three groups of isolates (Table 3).

There were no observable differences in the growth for $C$. manginecans isolates from mango and the isolates from $P$. cineraria and $D$. sissoo. No growth occurred in any of the isolates at $5{ }^{\circ} \mathrm{C}, 10{ }^{\circ} \mathrm{C}$ and $35^{\circ} \mathrm{C}$. Optimum growth for all the Ceratocystis isolates occurred between $25^{\circ} \mathrm{C}$ and $30^{\circ} \mathrm{C}$. 
DNA extraction, amplification, sequencing and phylogenetic analyses

The total number of characters in the ITS dataset after alignment and inclusion of gaps was $560 \mathrm{bp}$. The parsimony analysis for the ITS gene region was based on 117 parsimony informative characters, which resulted in six most parsimonious trees with a tree length of 131 steps, consistency index (CI) of 0.970 and a retention index (RI) of 0.979 . The phylogenetic analysis for the ITS gene region divided all the isolates from mango, $P$. cineraria and D. sissoo from Pakistan and Oman into two, well supported clades. Two isolates from P. cineraria (CMW17225 and CMW17568) grouped together with the isolates of $C$. manginecans from mango and A. crassicarpa designated as Group 2 in the study of Tarigan et al. (2011; Fig. 2a). All the D. sissoo isolates and two P. cineraria isolates (CMW17568 and CMW17570) resided in Group 1 with isolates of C. acaciivora from Acacia mangium (posterior probability value $(\mathrm{PP})=100 \%$, bootstrap value $(\mathrm{BP})=$ $96 \%)$.

As a consequence of the placement of the $P$. cineraria isolates from Oman into two different Ceratocystis groups (Fig. 2a) based on ITS sequences with $C$. manginecans residing in Group 2 and $C$. acaciivora residing in Group 1, all sequencing of the ITS region were repeated. Repeated sequencing of the isolates revealed that a single isolate (CMW17568) from $P$. cineraria contained both of the ITS sequences that define Groups 1 and Group 2 as different species. Sequence variability between these two groups was represented by a seven bp sequence difference in the ITS1 region that included 5 singlebase indels and 2 base substitutions, and a single indel in the ITS2 region (Table 4).

The total number of characters after alignment and inclusion of gaps for the BT sequence data was $551 \mathrm{bp}$. The maximum parsimony analysis was based on 26 informative characters and resulted in one tree with a tree length of 26 steps and a CI and RI value of 1. 
The BT sequences for $P$. cineraria and D. sissoo were $100 \%$ identical to those of $C$. manginecans from mango in Oman and Pakistan. In addition, there was no resolution in the sequence alignments between the Ceratocystis isolates in this study and those of the species C. manginecans and C. acaciivora. All the BT sequences from Oman, Pakistan and Indonesia used in this study were identical and formed a weakly supported monophyletic clade (PP=64 \%, BP=63\%) (Fig. 2b).

The total number of characters after alignment and inclusion of gaps for the TEF$1 \alpha$ sequence data was $756 \mathrm{bp}$. The maximum parsimony analysis yielded more than 100 trees using 39 informative characters. Tree length was 52 steps and the CI and RI values were 0.788 and 0.814 respectively. Sequence alignment for the TEF- $1 \alpha$ revealed no significant phylogenetic difference between the isolates from P. cineraria and D. sissoo with those of $C$. manginecans and C. acaciivora, which all clustered together ( $\mathrm{PP}=100 \%$, $\mathrm{BP}=93 \%)($ Fig. $2 \mathrm{c})$.

Inoculation trials

All $P$. cineraria seedlings inoculated in the first trial with isolates from $P$. cineraria and $C$. manginecans exhibited vascular discolouration with $59 \%(19 / 32)$ of inoculated seedlings beginning to die at the end of the experiment. Analysis of variance for lesion length in $P$. cineraria showed no significant differences in lesion lengths among all the isolates inoculated onto this host. Both isolates of $C$. manginecans from mango (CMW13851 and CMW13854) and the Ceratocystis isolates from P. cineraria (CMW17568 and CMW17570) gave rise to long lesions in P. cineraria seedlings ranging from $138.8 \mathrm{~mm}$ to $197.5 \mathrm{~mm}$. Furthermore, statistical analyses showed significant differences in lesion length between treated $P$. cineraria and the control seedlings $(6.3 \mathrm{~mm})$ (Fig. 3). Re-isolation from 
inoculated seedlings yielded a Ceratocystis sp. and the fungus was not isolated from the control seedlings.

All mango seedlings inoculated with $C$. manginecans and Ceratocystis isolates from $P$. cineraria and D. sissoo showed typical symptoms of mango wilt disease. The symptoms included extensive vascular discolouration in all inoculated seedlings and wilt was recorded in over $66 \%(12 / 18)$ of the inoculated seedlings. There were no significant differences in lesion length produced by the Ceratocystis isolates used in the inoculations. Average lesion lengths produced by the C. manginecans isolates (CMW13851 and CMW13854) from mango, Ceratocystis isolates from P. cineraria (CMW17225 and CMW17568) and from D. sissoo (CMW23623 and CMW23625) inoculated into mango seedlings were 406.7, 300, 266.7, 300, 300 and $263.3 \mathrm{~mm}$ respectively (Fig. 4a). The average lesion length on the control seedlings $(58.3 \mathrm{~mm})$ was significantly smaller than those for all the test plants.

P. cineraria seedlings inoculated with different isolates of Ceratocystis showed wilt symptoms in $72 \%(13 / 18)$ of the inoculated seedlings. Analysis of variance for lesion length in $P$. cineraria seedlings revealed no significant differences between the isolates tested (Fig. 4b). The lesion lengths produced on the $P$. cineraria seedlings inoculated with the Ceratocystis isolates ranged from 80 to $193.3 \mathrm{~mm}$, which was significantly different from those for the controls that had an average lesion length of $5 \mathrm{~mm}$.

D. sissoo seedlings inoculated with different Ceratocystis isolates showed mortality in four of $18(22 \%)$ seedlings. Isolates from P. cineraria, D. sissoo and C. manginecans did not differ significantly in their ability to cause lesions on D. sissoo plants (Fig.4c). Although longer lesions were produced on D. sissoo seedlings inoculated with the different Ceratocystis isolates (ranging from 63.3 to $120 \mathrm{~mm}$ ) there were no significant differences 
in lesion lengths of the majority of the Ceratocystis isolates compared to those for the control inoculations where the average lesion length was $5 \mathrm{~mm}$.

Re-isolation from a sub-set of inoculated seedlings representing the three hosts yielded cultures of a Ceratocystis sp. indistinguishable from the inoculated fungus. No Ceratocystis isolates were retrieved from control seedlings for any of the three hosts.

\section{Discussion}

In this study, $P$. cineraria and $D$. sissoo, were found to represent two new leguminous hosts for $C$. manginecans. In Oman, where the pathogen was first discovered (Al Adawi et al. 2006; Van Wyk et al. 2007), P. cineraria trees showed typical symptoms of infection by the fungus; the same was true in Pakistan for $D$. sissoo. The fact that $C$. manginecans, a serious wilt pathogen of mango in Oman (Al Adawi et al. 2006; Van Wyk et al. 2007) and Pakistan (Kazmi et al. 2005; Van Wyk et al. 2007), is infecting native trees in these countries is serious and could potentially lead to the devastation of important components of the natural biodiversity of Oman and Pakistan.

The identity of $C$. manginecans as the fungus associated with the wilt disease of $P$. cineraria and D. sissoo was determined based on morphological characteristics as well as DNA sequence comparisons. In addition, the pathogenicity of $C$. manginecans to both these hosts was demonstrated in inoculation trials and it is clear that the fungus is responsible for the widespread death of these trees. It was also possible to show that isolates of the pathogen from these trees are able to infect and kill mango plants.

Ceratocystis manginecans is best known due to the severe damage that it has caused on mango in Oman and Pakistan (Kazmi et al. 2005; Al Adawi et al. 2006; Van Wyk et al. 2007). But it has recently also been found, together with $C$. acaciivora, killing 
Acacia mangium in Indonesia (Tarigan et al. 2011). This is particularly interesting because A. mangium, like $P$. cineraria and $D$. sissoo, is a leguminous tree. This supports the view that $C$. manginecans has a host range beyond mango and in time it might be found to infect other trees.

Ceratocystis manginecans forms part of the $C$. fimbriata s. 1. complex, which is typified by $C$. fimbriata sensu stricto that causes black rot of sweet potato (Engelbrecht and Harrington 2005). Phylogenetic inference based on DNA sequence comparisons has made it possible to distinguish many different lineages in the complex and some of these have been treated as distinct species (Wingfield et al. 1996; Barnes et al. 2003; Engelbrecht and Harrington 2005; Johnson et al. 2005; Van Wyk et al. 2007; Rodas et al. 2008; Van Wyk et al. 2009; 2010; 2011). Most of these species can also be distinguished based on morphological characters although these are subtle and experience with all the members of the group is needed to clearly recognise them.

The ITS region has been used as the primary gene region with which to distinguish species in Ceratocystis and in fungi as a whole (Lieckfeldt and Seifert 2000; Van Wyk et al. 2009; 2010; 2011). It has been identified as a barcoding gene (Rossman 2007; Seifert 2009; Schoch et al. 2012) and just a few base changes in this sequence can define closely related, yet distinct species. The discovery of two ITS types in one isolate in $C$. manginecans in this study is not unusual (O'Donnell and Cigelnik 1997; Ko and Jung 2002; Pannecoucque and Höfte 2009) but suggests caution be applied when using this gene region to infer support for the delineation of species in the Ceratocystis species complex. This is especially in light of the fact that one of the ITS types in $C$. manginecans has exactly the same sequence that defines C. acaciivora. Although the combined phylogeny of three gene regions strongly supported the separation of $C$. manginecans and $C$. acaciivora (Tarigan et al. 2011), when analyzed separately, no resolution between these 
two species was evident in either the $\beta$-tubulin or EF 1- $\alpha$ phylogenies. This implies that most of the phylogenetic signal arose from the ITS region. The result of the present study questions the validity of $C$. acaciivora and further work is on-going to resolve this question.

The mango disease caused by $C$. manginecans in Oman and Pakistan is closely associated with the wood-boring insect $H$. mangiferae (Al Adawi et al. 2006; Al Adawi et al. 2012). This insect is native to south East Asia including the native range of mango and it is apparently specific to these trees (Castro 1960; Butani 1993; Atkinson and Peck 1994; Pena and Mohyuddin 1997). No insects were found associated with the wilt disease of $P$. cineraria and D. sissoo reported in this study. However, Ceratocystis spp. require wounds to infect trees and it is possible that wood boring insects vector the pathogen; alternatively it may be carried to wounds on trees by opportunistic insects such as nitidulid beetles that are well-recognised as vectors of Ceratocystis spp. in the C. fimbriata s. 1. complex (Moller and De Vay 1968b; Heath et al. 2009; Roux and Wingfield 2009).

The wilt disease of $P$. cineraria and $D$. sissoo appears to be serious and it is clearly a new host tree/pathogen association (Roy 2001) that has apparently occurred due to a host shift (Slippers et al. 2005). This category of diseases is increasing in importance and they have the capacity to devastate native trees that have not previously encountered them (Roy 2001; Anderson et al. 2004; Slippers et al. 2005; Woolhouse et al. 2005; Desprez-Loustau et al. 2007; Wingfield et al. 2010). In this regard, the wilt disease of $P$. cineraria and $D$. sissoo has the capacity to impact seriously on the natural diversity of Oman and Pakistan and studies should be instituted to understand them better. 
Acknowledgement We thank members of the Tree Protection Co-operative Programme (TPCP), University of Pretoria, South Africa, and the Ministry of Agriculture and Fisheries, Oman, for funding and providing facilities to conduct this study. We also thank the Nuclear Institute for Agriculture and Biology (NIAB) for facilitating surveys and shisham sample collection in Pakistan.

\section{References}

Al Adawi AO (2002) The Biology of Diplodia theobromae associated with Mango Sudden Decline Disease in Oman. Dissertation, Sultan Qaboos University

Al Adawi AO, Deadman ML, Al Rawahi AK, Khan AJ, Al Maqbali YM (2003) Diplodia theobromae associated with sudden decline of mango in the Sultanate of Oman. Plant Pathology 52:419

Al Adawi AO, Deadman ML, Al Rawahi AK, Al Maqbali YM, Al Jahwari AA, Al Saadi BA, Al Amri IS, Wingfield MJ (2006) Aetiology and causal agents of mango sudden decline disease in the Sultanate of Oman. European Journal of Plant Pathology $116: 247-254$

Al Adawi AO, Barnes I, Al Jahwari AA, Deadman ML, Wingfield BD, Wingfield MJ (2009) Discovery of a Ceratocystis sp. associated with wilt disease of two native leguminous tree hosts in Oman and Pakistan. Australian Plant Pathology Society meeting (APPS 2009) 'Plant health management: An integrated approach'. 29 September - 1 October 2009

Al Adawi AO, Al Jabri RM, Deadman ML, Barnes I, Wingfield BD, Wingfield MJ (2012) The mango sudden decline pathogen, Ceratocystis manginecans, is vectored by Hypocryphalus mangiferae (Coleoptera: Scolytinae) in Oman. European Journal of Plant Pathology In press 
Anderson PK, Cunningham AA, Patel NG, Morales FJ, Epstein PR, Daszak P (2004) Emerging infectious diseases of plants: pathogen pollution, climate change and agrotechnology drivers. Trends in Ecology and Evolution 19:535-544

Atkinson TH, Peck SB (1994) Annotated checklist of the bark and ambrosia beetles (Coleoptera: Platypodidae and Scolytidae) of tropical Southern Florida. Florida Entomologist Online 77:313-329

Barnes I, Roux J, Coetzee MPA, Wingfield BD, Wingfield MJ (2001) Characterization of Seiridium spp. associated with Cypress Canker based on B-tubulin and histone sequence. Plant Disease 85:317-321

Barnes I, Roux J, Wingfield BD, Dudzinski MJ, Old KM, Wingfield MJ (2003) Ceratocystis pirilliformis, a new species from Eucalyptus nitens in Australia. Mycologia 95:865-871

Brown K (1991) Biology of Prosopis cineraria (Leguminosae) in the Sultanate of Oman. Dissertation, University of Durham

Brown K (1992) Prosopis cineraria research in Oman. Directorate General of Agricultural Research, Rumais, Ministry of Agriculture and Fisheries, Sultanate of Oman

Butani DK (1993) Mango: Pest Problems. Periodical Expert Book Agency D- 42, Vivek Vihar, Delhi

CAB International (2001) Ceratocystis fimbriata (original text by Harrington, T. C. and Baker, C.). In: Crop protection compendium. CAB International, Wallingford Castro RS (1960) Contribuicao ao estudo de Hypocryphalus mangiferae (Stebbing, 1914) (Coleoptera, Scolytidae). [Contribution to the study of the "Hypocryphalus mangiferae (Stebbing, 1914)" (Coleopter - Scolytidae) biological cycle and etiology] Ciclo biologico e etiologia. Recife. Tese para concurso de professor livre-docente da 9. ${ }^{\mathrm{a}}$ 
cadeira-entomologia e parasitologia agricolas- da Escola Superior de Agricultura da Universidade Rural de Pernambuco, 54p

Desprez-Loustau ML, Robin C, Buee M, Courtecuisse R, Garbaye J, Suffert F, Sache I, Rizzo DM (2007) The fungal dimension of biological invasions. Trends in Ecology and Evolution 22:472-480

Engelbrecht CJB, Harrington TC (2005) Intersterility, morphology and taxonomy of Ceratocystis fimbriata on sweet potato, cacao and sycamore. Mycologia 97:57-69

Glass NL, Donaldson GC (1995) Development of primer sets designed for use with the PCR to amplify conserved genes from filamentous Ascomycetes. Applied and Environmental Microbiology 61:1323-1330

Halsted BD, Fairchild DG (1891) Sweet-potato black rot. Journal of Mycology 7:1-11.

Heath RN, Wingfield MJ, Van Wyk M, Roux J (2009) Insect Associates of Ceratocystis albifundus and Patterns of Association in a Native Savanna Ecosystem in South Africa. Environmental Entomology 38:356-364

Johnson JA, Harrington TC, Engelbrecht CJB (2005) Phylogeny and taxonomy of the North American clade of the Ceratocystis fimbriata complex. Mycologia 97:1067-1092 Jacobs K, Bergdahl DR, Wingfield MJ, Halik S, Seifert KA, Bright DE, Wingfield BD (2004) Leptographium wingfieldii introduced into North America and found associated with exotic Tomicus piniperda and native bark beetles. Mycological Research 108:411418

Kazmi M. R. Fateh, F. S. Majeed, K. Kashkhely, A. M. Hussain, I. Ahmad, I. Jabeen, A (2005) Incidence and etiology of mango sudden death phenomenon in Pakistan. Pakistan Journal of Phytopathology 17:154-158 
Khan SH, Idrees M, Muhammad F, Mahmood A, Zaidi SH (2004) Incidence of Shisham (Dalbergia sissoo Roxb.) decline and in vitro response of isolated fungus spp. to various fungicides. International Journal of Agriculture and Biology 6:611-614

Kile GA (1993) Plant diseases caused by species of Ceratocystis sensu stricto and Chalara. In: Wingfield MJ, Seifert KA, Webber JF (eds) Ceratocystis and Ophiostoma: Taxonomy, Ecology and Pathogenicity. APS Press, St Paul, USA, pp $173-183$

Ko KS, Jung HS (2002) Three nonorthologous ITS1 types are present in a polypore fungus Trichaptum abietinum. Molecular Phylogenetics and Evolution 23:112-122.

Malik MT, Khan SM, Dasti AA, Kazmi MR (2005) First record of Ceratocystis fimbriata, causal organism of mango sudden death in Pakistan. Pakistan Journal of Phytopathology 17:187-191

Moller WJ, DeVay JE (1968a) Carrot as a species-selective isolation medium for Ceratocystis fimbriata. Phytopathology 58:123-124

Moller WJ, DeVay JE (1968b) Insect transmission of Ceratocystis fimbriata in deciduous fruit orchards. Phytopathology 58:1499-1508

Morris MJ, Wingfield MJ, De Beer C (1993) Gummosis and wilt of Acacia mearnsii in South Africa caused Ceratocystis fimbriata. Plant Pathology 42:814-817

Nylander JAA (2004) MrModeltest v2. Program distributed by the author. Evolutionary Biology Centre, Uppsala University

O’Donnell K, Cigelnik E (1997) Two divergent intragenomic rDNA ITS2 types within a monophyletic lineage of the fungus Fusarium are nonorthologous. Molecular Phylogenetics and Evolution 7:103-116.

Pannecoucque J, Höfte M (2009) Detection of rDNA ITS polymorphism in Rhizoctonia solani AG 2-1 isolates. Mycologia 101:26-33. 
Pena JE, Mohyuddin AI (1997) Insect Pests. In: Litz RE. (ed) The Mango: Botany, Production and Uses. CAB International, Wallingford, UK, pp. 327-362

Ploetz RC (2003) Diseases of Mango. In: Ploetz RC. (ed) Diseases of Tropical Fruit Crops. CAB International, Wallingford, UK, pp 327-363

Poussio GB, Kazmi MR, Akem C, Fateh FS (2010) First record of Ceratocystis fimbriata associated with shisham (Dalbergia sissoo) decline in Pakistan. Australasian Plant Disease Notes 5:63-65

Rannala B, Yang Z (1996) Probability distribution of molecular evolutionary trees: a new method of phylogenetic inference. Journal of Molecular Evolution 43:304-311

Rodas CA, Roux J, van Wyk M, Wingfield BD, Wingfield MJ (2008) Ceratocystis neglecta sp. nov., infecting Eucalyptus trees in Colombia. Fungal Diversity 28:73-84

Ronquist F, Huelsenbeck JP (2003) MrBayes3: Bayesian phylogenetic inference under mixed models. Bioinformatics 19:1572-1574

Roux J, Wingfield MJ (2009) Ceratocystis species: emerging pathogens of non-native plantation Eucalyptus and Acacia species. Southern Forests 71:115-120

Roy BA (2001) Patterns of association between crucifers and their flower-mimic pathogens: Host jumps are more common than co-evolution or co-speciation. Evolution $55: 41-53$

Schoch CL, Seifert KA, Huhndorf S, Robert V, Spouge JL, Levesque CA, Chen W, Fungal Barcoding Consortium (2012) Nuclear ribosomal internal transcribed spacer (ITS) region as a universal DNA barcode marker for Fungi. Proceedings of the Natural Academy of Science USA 109:6241-6246.

Slippers B, Stenlid J, Wingfield MJ (2005) Emerging pathogens: fungal host jumps following anthropogenic introduction. Trends in Ecology and Evolution 20:420-421 
Swofford DL (2002) PAUP*. Phylogenetic Analysis Using Parsimony (*and other methods). Version 4. Sinauer Associates: Sunderland, MA

Tamura K, Peterson D, Peterson N, Stecher G, Nei M, Kumar S (2011) MEGA5: Molecular Evolutionary Genetics Analysis using Maximum Likelihood, Evolutionary Distance, and Maximum Parsimony Methods. Molecular Biology and Evolution 28:2731-2739.

Tantau H, Hoque MI, Sarker RH, Muhlbach HP (2005) 16S rDNA sequence analysis of bacterial isolates from dieback affected Sissoo trees (Dalbergia sissoo Roxb.) in Bangladesh. Journal of Phytopathology 153:517-521

Tarigan M, Roux J, Van Wyk M, Tjahjono B, Wingfield MJ (2011) A new wilt and dieback disease of Acacia mangium associated with Ceratocystis manginecans and $C$. acaciivora sp. nov. in Indonesia. South African Journal of Botany 77:292-304

Upadhyay HP (1981) A monograph of Ceratocystis and Ceratocystiopsis. University of Georgia Press, Athens

Van Wyk M, Al Adawi AO, Khan IA, Deadman ML, Al Jahwari A, Wingfield BD, Ploetz RC, Wingfield MJ (2007) Ceratocystis manginecans sp. nov., causal disease of a destructive mango wilt disease in Oman and Pakistan. Fungal Diversity 27:213-230

Van Wyk M, Wingfield BD, Mohali S, Wingfield MJ (2009) Ceratocystis fimbriatomima, a new species in the $C$. fimbriata sensu lato complex isolated from Eucalyptus trees in Venezuela. Fungal Diversity 34:173-183

Van Wyk M, Wingfield BD, Marin M, Wingfield MJ (2010) New Ceratocystis species infecting coffee, cacao, citrus and native trees in Colombia. Fungal Diversity 40:103117 
Van Wyk M, Wingfield BD, Wingfield MJ (2011) Four new Ceratocystis spp. associated with wounds on Eucalyptus, Schizolobium and Terminalia trees in Ecuador. Fungal Diversity 40:103-117

Viegas AP (1960) Seca da mangueira (Mango Wilt). Bragantia 19:163-182.

White TJ, Burns T, Lee S, Taylor J (1990) Amplification and direct sequencing of fungal ribosomal RNA genes for phylogenetics. In: Innis MA, Gelfand DH, Sninsky JJ, White TJ, eds. PCR protocols: A sequencing guide to methods and applications. San Diego, California: Academic Press. pp 315-322

Wingfield MJ, De Beer C, Visser C, Wingfield BD (1996) A new Ceratocystis species defined using morphological and ribosomal DNA sequence comparisons. Systematic and Applied Microbiology 19:191-202

Wingfield MJ, Slippers B, Wingfield BD (2010) Novel association between pathogens, insects and tree species threaten world forests. New Zealand Journal of Forestry Science 40:S95-S103

Woolhouse MEJ, Haydon DT, Antia R (2005) Emerging pathogens: the epidemiology and evolution of species jumps. Trends in Ecology and Evolution 20:238-244 
Table 1 Ceratocystis isolates used in the morphological comparisons, phylogenetic analyses and inoculation trials

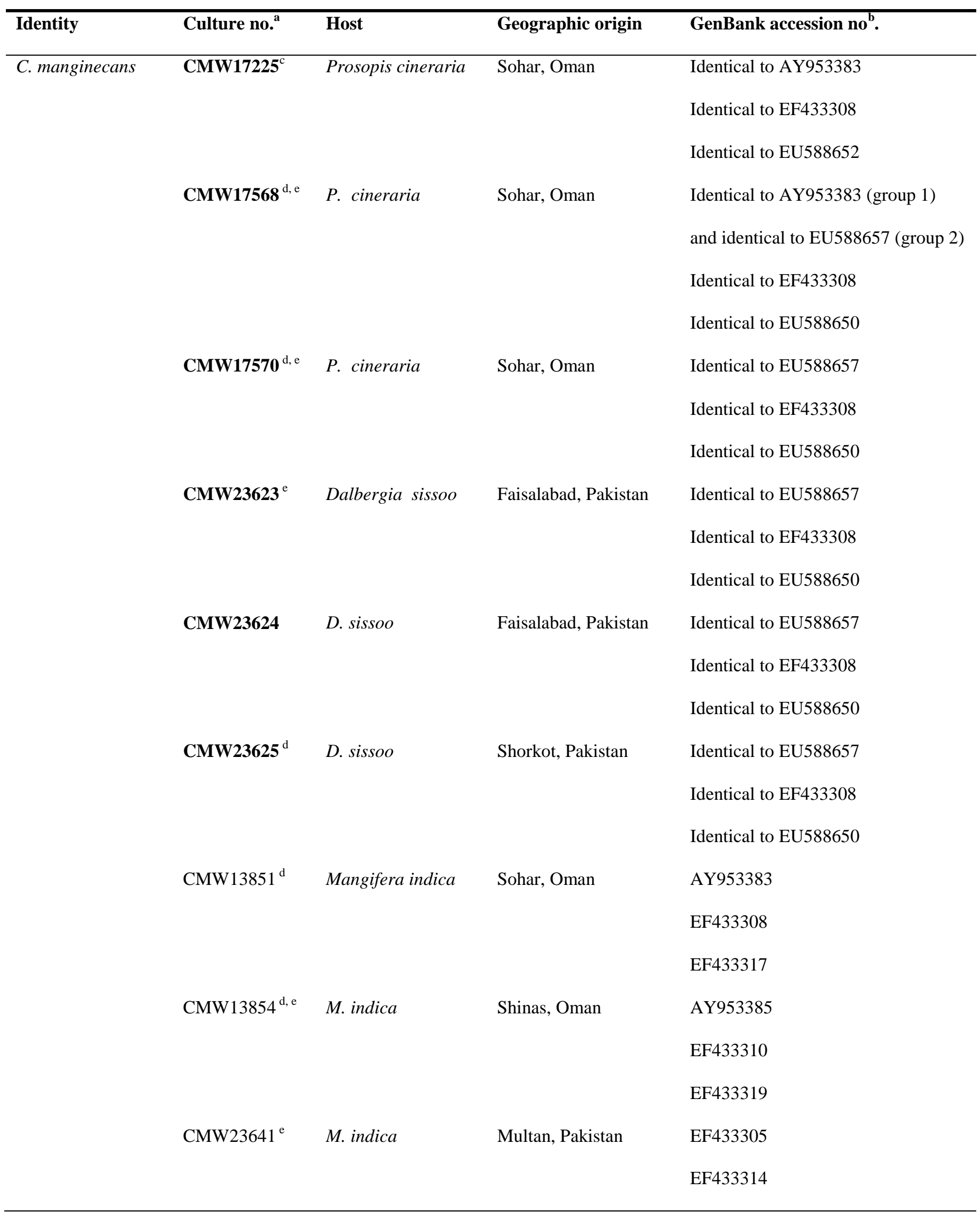




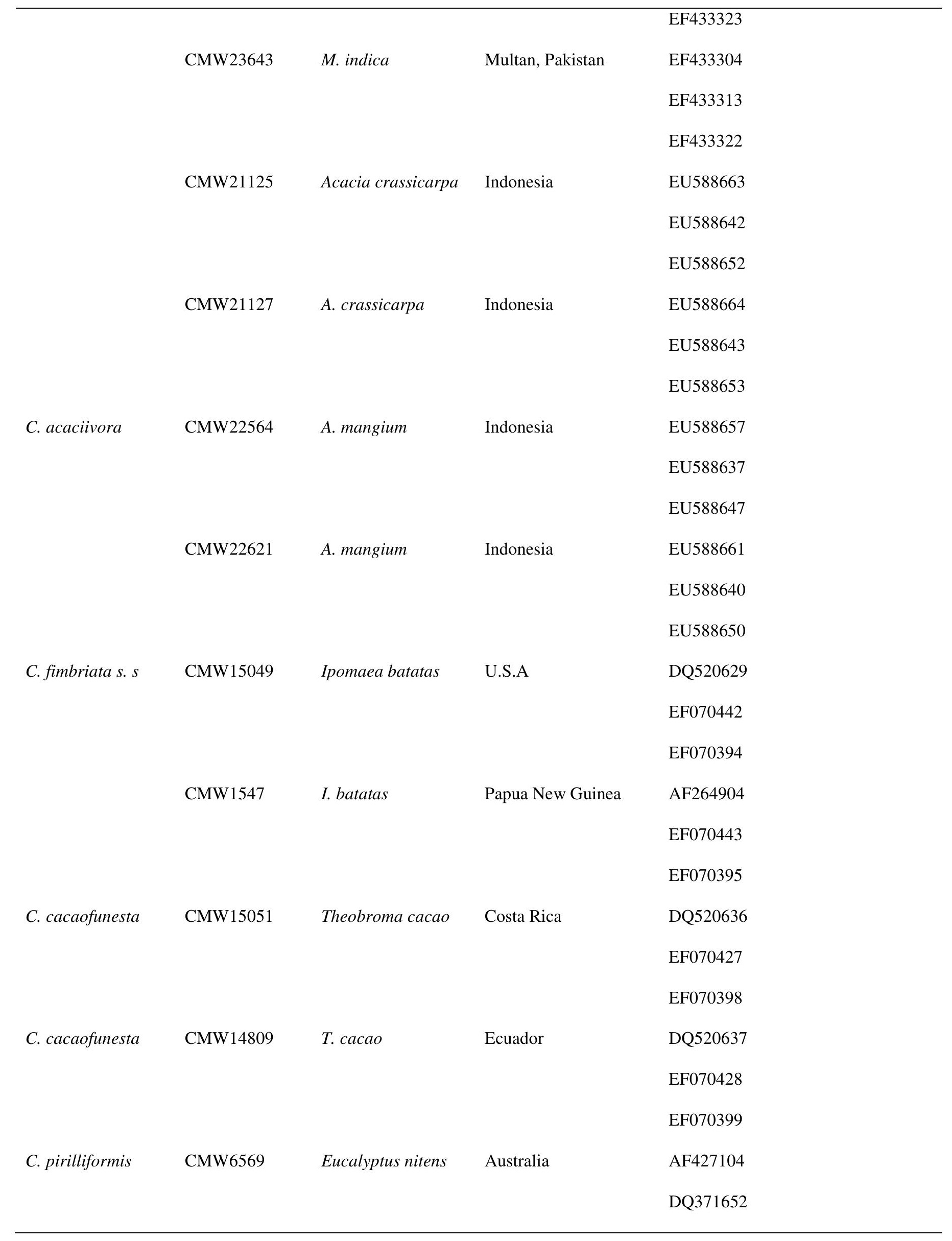


AY528982

CMW6579

E. nitens

Australia

AF427105

DQ371653

AY528983

\footnotetext{
${ }^{\mathrm{a}}$ Culture collection of the Forestry and Agricultural Biotechnology Institute (FABI), University of Pretoria,

South Africa

${ }^{\mathrm{b}}$ GenBank accession number for the ITS, $\beta$-tubulin and EF sequences respectively, for each isolate

${ }^{\mathrm{c}}$ Isolates in bold were sequenced during this study

${ }^{\mathrm{d}}$ Isolates used in the inoculation trial

${ }^{\mathrm{e}}$ Isolates used in the morphological characterizations
}

Table 2 Recovery of Ceratocystis manginecans from carrot baiting and moist chambers from samples collected from dying Prosopis cineraria and Dalbergia sissoo trees in Oman and Pakistan

\begin{tabular}{|c|c|c|c|c|}
\hline \multirow{2}{*}{$\begin{array}{l}\text { Host } \\
\text { P. cineraria }\end{array}$} & \multirow{2}{*}{$\begin{array}{l}\text { Area } \\
\text { Sohar }\end{array}$} & \multirow{2}{*}{$\begin{array}{l}\text { Year } \\
2004\end{array}$} & \multicolumn{2}{|c|}{ Recovery of $C$. manginecans } \\
\hline & & & & $1 / 4 \quad(25 \%)$ \\
\hline & & 2005 & & $3 / 6 \quad(50 \%)$ \\
\hline & & 2006 & & $3 / 5 \quad(60 \%)$ \\
\hline & & & Total & 7/15 (46.7\%) \\
\hline \multirow[t]{5}{*}{ D. sissoo } & Faisalabad & 2006 & & $3 / 6 \quad(50 \%)$ \\
\hline & Shorkot & & & $2 / 7 \quad(28.6 \%)$ \\
\hline & Chenab Nagar & & & $2 / 4 \quad(50 \%)$ \\
\hline & Multan & & & $0 / 1 \quad(0 \%)$ \\
\hline & & & Total & 7/18 (38.9\%) \\
\hline
\end{tabular}


Table 3 Morphology of selected Ceratocystis manginecans isolates from mango, $P$. cineraria and $D$. sissoo

\begin{tabular}{|c|c|c|c|c|c|c|c|c|}
\hline \multirow{2}{*}{$\begin{array}{l}\text { Isolates/ } \\
\text { Morphological } \\
\text { characters }^{\mathrm{a}}\end{array}$} & \multirow[b]{2}{*}{$P$ value } & \multicolumn{3}{|c|}{ Mango } & \multirow{2}{*}{$\begin{array}{l}\text { P. cinerea } \\
\text { CMW17568 }\end{array}$} & \multirow[b]{2}{*}{ CMW17570 } & \multirow[b]{2}{*}{ Mean } & \multirow[b]{2}{*}{ CMW236 } \\
\hline & & CMW13854 & CMW23641 & Mean & & & & \\
\hline Neck (l) & $p<0.0001$ & $543.24 b^{c}$ & $518.27 b$ & $530.75 c$ & $525.51 \mathrm{~b}$ & $620.67 a$ & $620.67 a$ & $620.67 \mathrm{a}$ \\
\hline Neck (w) top & $p<0.0001$ & $20 \mathrm{a}$ & $17.36 \mathrm{~b}$ & 18.68a & $17.56 \mathrm{~b}$ & $17.74 b$ & $17.65 b$ & $18.79 \mathrm{ab}$ \\
\hline Neck (w) bottom & $p=0.1805$ & $38.22 \mathrm{a}$ & $29.96 \mathrm{a}$ & 34.09a & $33.79 \mathrm{a}$ & $31.03 \mathrm{a}$ & $32.41 \mathrm{a}$ & $31.65 \mathrm{a}$ \\
\hline $\begin{array}{l}\text { Ascomatal base } \\
\text { (w) }\end{array}$ & $p<0.0018$ & $198.18 \mathrm{ab}$ & $178.31 b$ & 188.25a & $206.85 a$ & $186.94 \mathrm{ab}$ & $196.90 \mathrm{a}$ & $186.74 \mathrm{al}$ \\
\hline $\begin{array}{l}\text { Ascomatal base } \\
\text { (l) }\end{array}$ & $p<0.0024$ & $190.32 \mathrm{ab}$ & $185.66 \mathrm{ab}$ & 187.99a & $210.37 \mathrm{a}$ & $176.56 b$ & $193.47 a$ & $181.17 b$ \\
\hline $\begin{array}{l}\text { Ostiolar hyphae } \\
\text { (l) }\end{array}$ & $p<0.0003$ & $53.89 b$ & $57.94 a b$ & $55.92 b$ & $57.3 \mathrm{ab}$ & $61.24 \mathrm{ab}$ & $59.27 \mathrm{~b}$ & $64.29 \mathrm{a}$ \\
\hline $\begin{array}{l}\text { Hat-shaped } \\
\text { ascospores (l) }\end{array}$ & $p=0.4358$ & $3.47 \mathrm{a}$ & $3.32 \mathrm{a}$ & $3.39 \mathrm{a}$ & $3.42 \mathrm{a}$ & $3.3 \mathrm{a}$ & $3.36 \mathrm{a}$ & $3.33 \mathrm{a}$ \\
\hline $\begin{array}{l}\text { Ascospores (w) } \\
\text { without sheath }\end{array}$ & $p=0085$ & $4.9 \mathrm{~b}$ & $5.01 \mathrm{ab}$ & 4.95a & $5.16 \mathrm{ab}$ & $4.9 \mathrm{~b}$ & $5.03 a$ & $5.34 \mathrm{a}$ \\
\hline $\begin{array}{l}\text { Ascospores (w) } \\
\text { with sheath }\end{array}$ & $p=0.002$ & $6.03 b$ & $6.28 \mathrm{ab}$ & $6.16 \mathrm{a}$ & $6.08 \mathrm{ab}$ & 5.98 & $6.03 a$ & $6.5 \mathrm{a}$ \\
\hline $\begin{array}{l}\text { Primary conidia } \\
\text { (l) }\end{array}$ & $p=0.075$ & $22.72 \mathrm{ab}$ & $19.26 b$ & $20.99 a$ & $21.34 \mathrm{ab}$ & $21.98 \mathrm{ab}$ & $21.66 a$ & $22.2 \mathrm{ab}$ \\
\hline $\begin{array}{l}\text { Primary conidia } \\
\text { (w) }\end{array}$ & $p<0.0001$ & $4.24 b$ & $4.32 \mathrm{~b}$ & $4.28 b$ & $5.52 \mathrm{a}$ & $4.48 \mathrm{~b}$ & $5 \mathbf{a}$ & $4.3 b$ \\
\hline $\begin{array}{l}\text { Secondary } \\
\text { Conidia (l) }\end{array}$ & $p<0.0001$ & $9.79 a$ & $8.53 b$ & 9.16a & $10.22 \mathrm{a}$ & $8.66 b$ & $9.44 a$ & $8.17 \mathrm{~b}$ \\
\hline $\begin{array}{l}\text { Secondary } \\
\text { Conidia (w) }\end{array}$ & $p<0.0001$ & $6.8 \mathrm{a}$ & $6.2 b$ & $6.5 \mathrm{a}$ & $5.06 \mathrm{c}$ & $6.74 a$ & $5.90 \mathrm{~b}$ & $5.97 \mathrm{~b}$ \\
\hline $\begin{array}{l}\text { Chlamydospores } \\
\text { (l) }\end{array}$ & $p=0.0361$ & $13.58 \mathrm{a}$ & $12.99 \mathrm{a}$ & $13.29 \mathrm{a}$ & $14.06 \mathrm{a}$ & $13.18 \mathrm{a}$ & $13.62 a$ & $13.9 \mathrm{a}$ \\
\hline Chlamydospores & $p<0.0020$ & $10.49 b$ & $11.13 \mathrm{ab}$ & $13.29 \mathrm{a}$ & $11.43 \mathrm{a}$ & $10.22 b$ & $13.62 \mathrm{a}$ & $10.78 \mathrm{ab}$ \\
\hline
\end{tabular}


(w)

\begin{tabular}{|c|c|c|c|c|c|c|c|c|c|}
\hline Culture $^{b}$ & $5^{\circ} \mathrm{C}$ & & 0 & 0 & 0 & 0 & 0 & 0 & 0 \\
\hline growth & $10^{\circ} \mathrm{C}$ & & 0 & 0 & 0 & 0 & 0 & 0 & 0 \\
\hline \multirow[t]{5}{*}{ rate at } & $15^{\circ} \mathrm{C}$ & $p<0.0001$ & $11 b$ & $9.3 c$ & $10.15 c$ & $13.9 \mathrm{a}$ & $12.8 \mathrm{a}$ & 13.35a & $11.1 \mathrm{~b}$ \\
\hline & $20^{\circ} \mathrm{C}$ & $p<0.0001$ & $20.7 \mathrm{ab}$ & $22.9 a$ & 22.1a & $20.7 b c$ & $19.3 c$ & $20 b$ & $19.6 b c$ \\
\hline & $25^{\circ} \mathrm{C}$ & $p=0.0022$ & $30.2 \mathrm{ab}$ & $32 \mathrm{a}$ & 31.1a & $31.9 \mathrm{a}$ & 29.8ab & 30.85a & $27.4 \mathrm{~b}$ \\
\hline & $30^{\circ} \mathrm{C}$ & $p<0.0001$ & $31 \mathrm{a}$ & $30.2 \mathrm{a}$ & $30.6 a$ & $26.4 b$ & $30.7 \mathrm{a}$ & 28.55b & $31.2 \mathrm{a}$ \\
\hline & $35^{\circ} \mathrm{C}$ & & 0 & 0 & $\mathbf{0}$ & 0 & 0 & $\mathbf{0}$ & 0 \\
\hline
\end{tabular}

\footnotetext{
${ }^{\mathrm{a}}$ All morphological characters represent an average for 25 measurements for each morphological structure measured in $\mu \mathrm{m}$

${ }^{\mathrm{b}}$ Growth rate measurements represent an average of diameters of cultures measured in mm at each temperature after seven days
}

${ }^{c}$ Means of isolates with the same letter are not significantly different according to Tukey test 
Table 4. Sequence variation in the two ITS types (Group 1 and Group 2) found in Ceratocystis manginecans isolates from $P$. cineraria, D. sissoo and mango

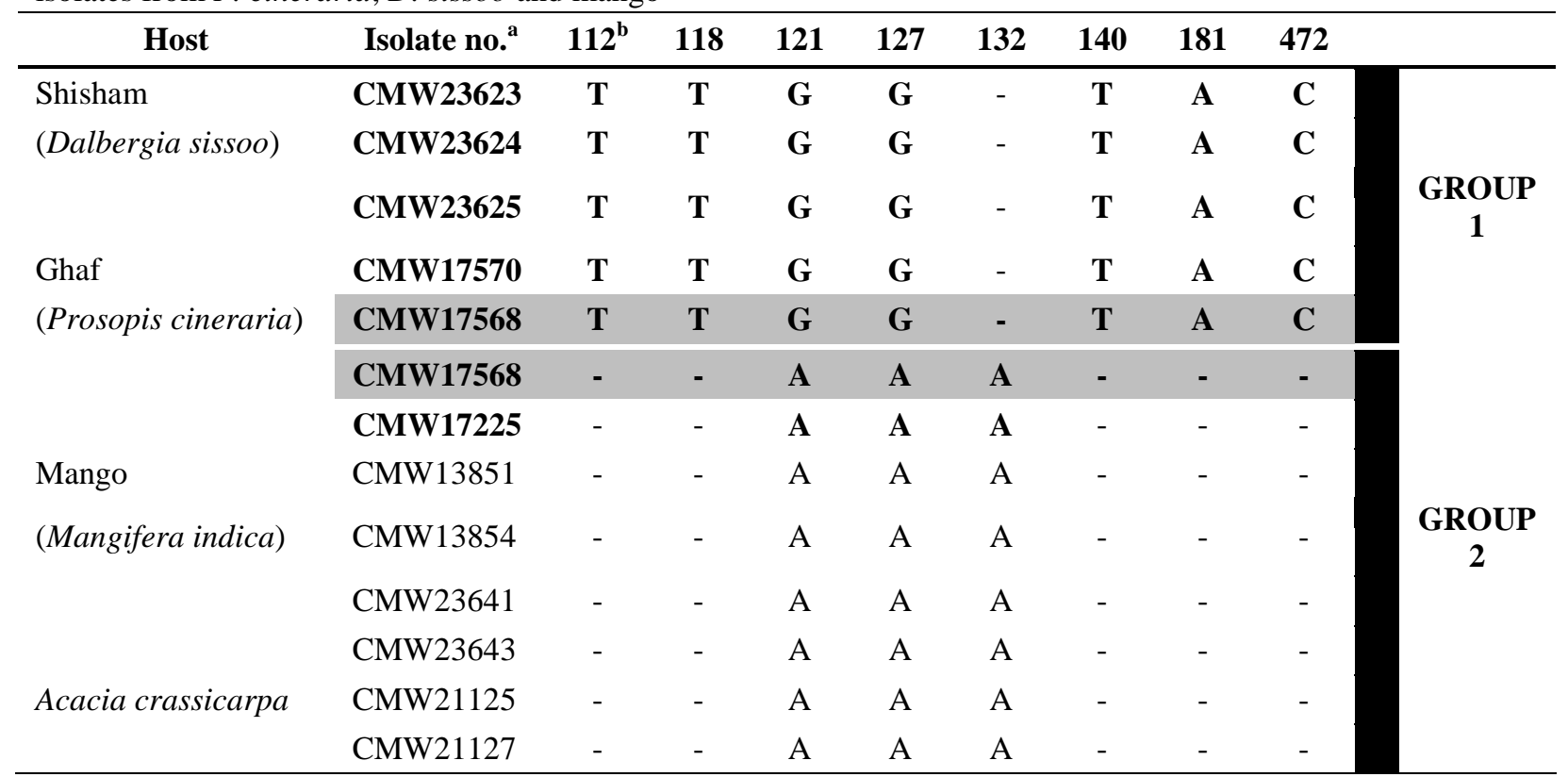

a The ITS region of all the isolates represented in bold were sequenced twice, using the same single spore culture to validate the results. The highlighted isolate contains both ITS types that was used to designate isolates into Group 1 and Group 2 in Tarigan et al. (2011) and Fig 2a

${ }^{\mathrm{b}}$ Nucleotide position after alignment 

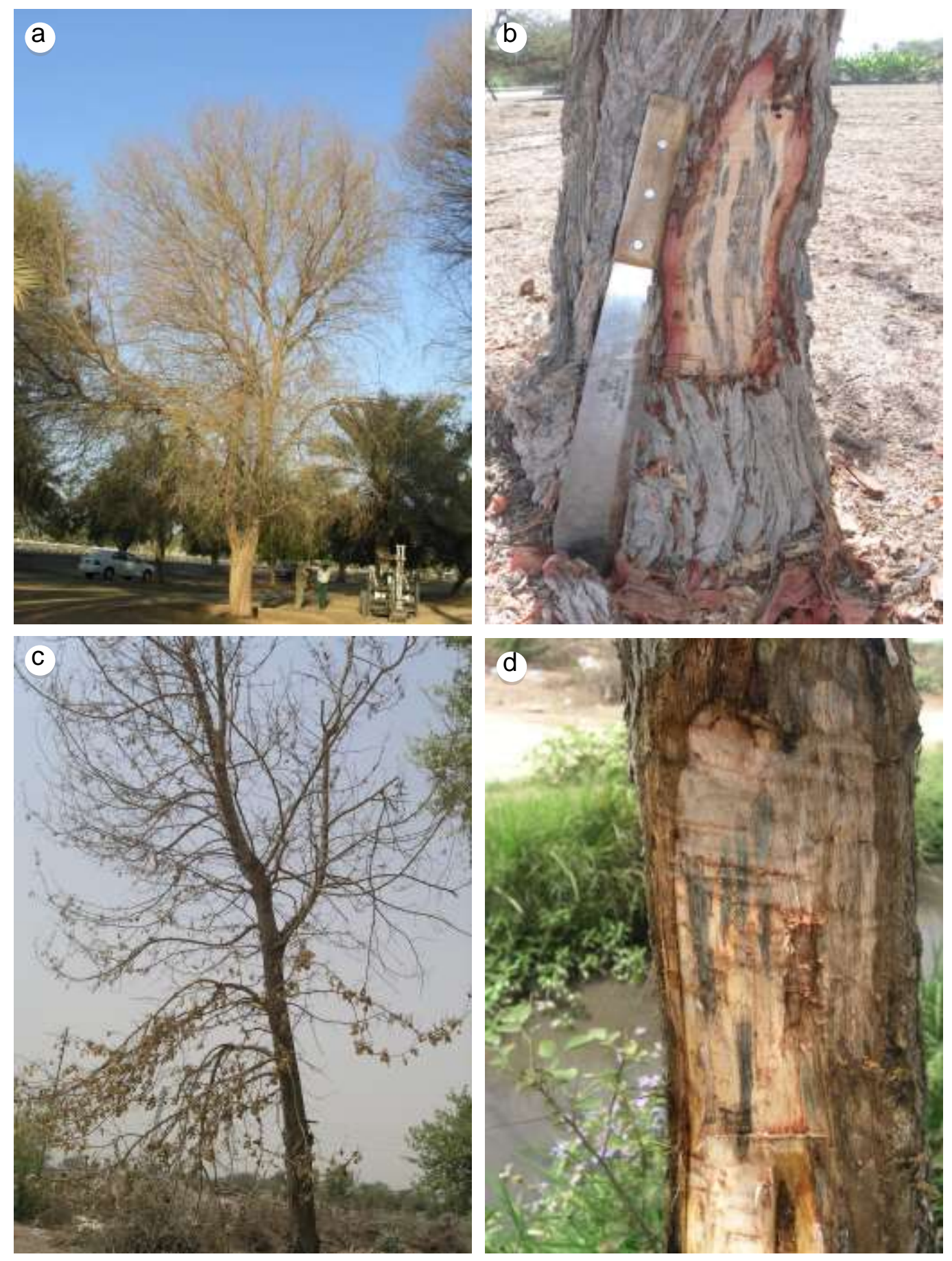

Fig. 1 Symptoms of wilt and die-back on $P$. cineraria and D. sissoo (a) wilted $P$. cineraria, (b) dark staining of the xylem tissues in P. cineraria, (c) dying D. sissoo tree, (d) vascular discolouration of infected D. sissoo 


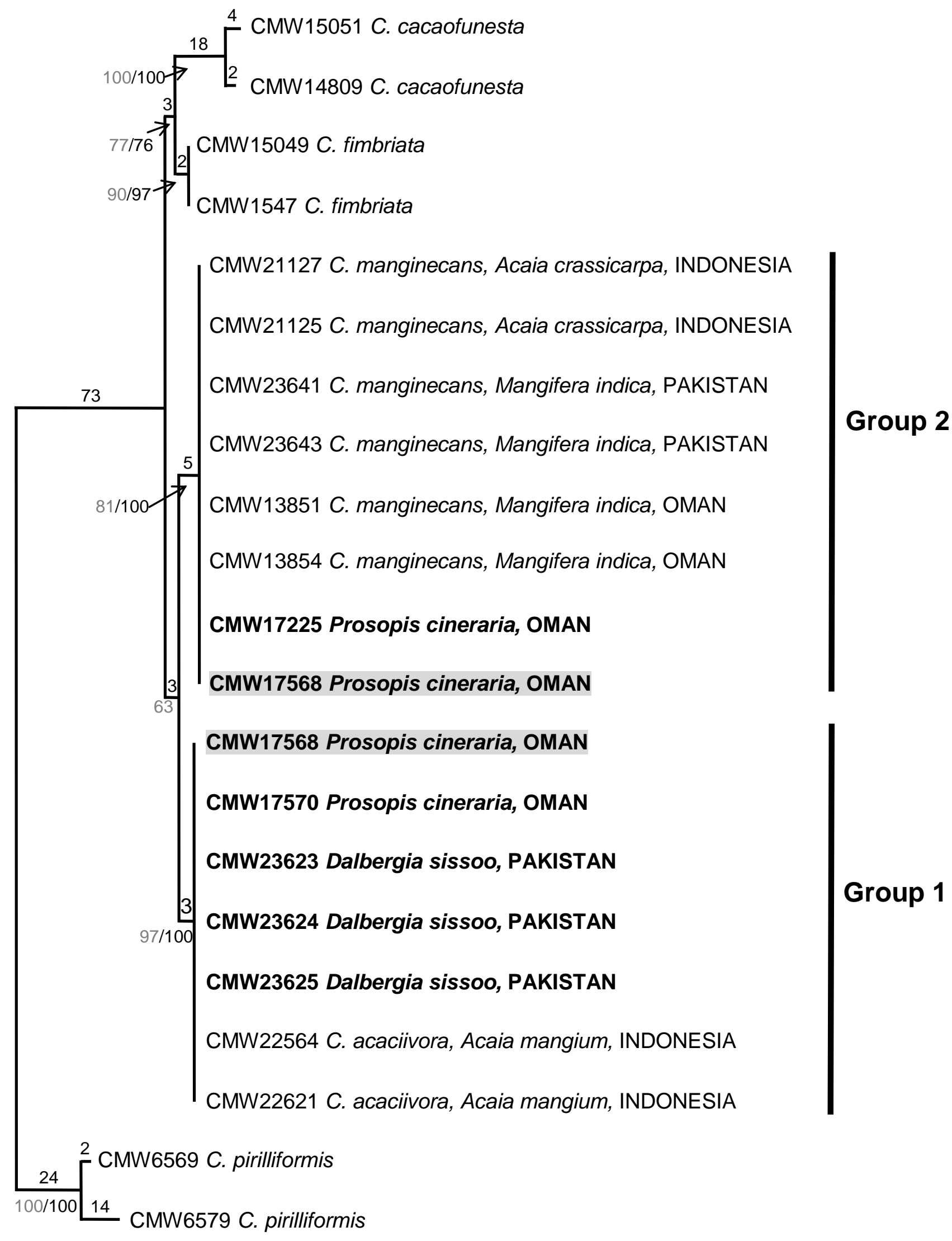




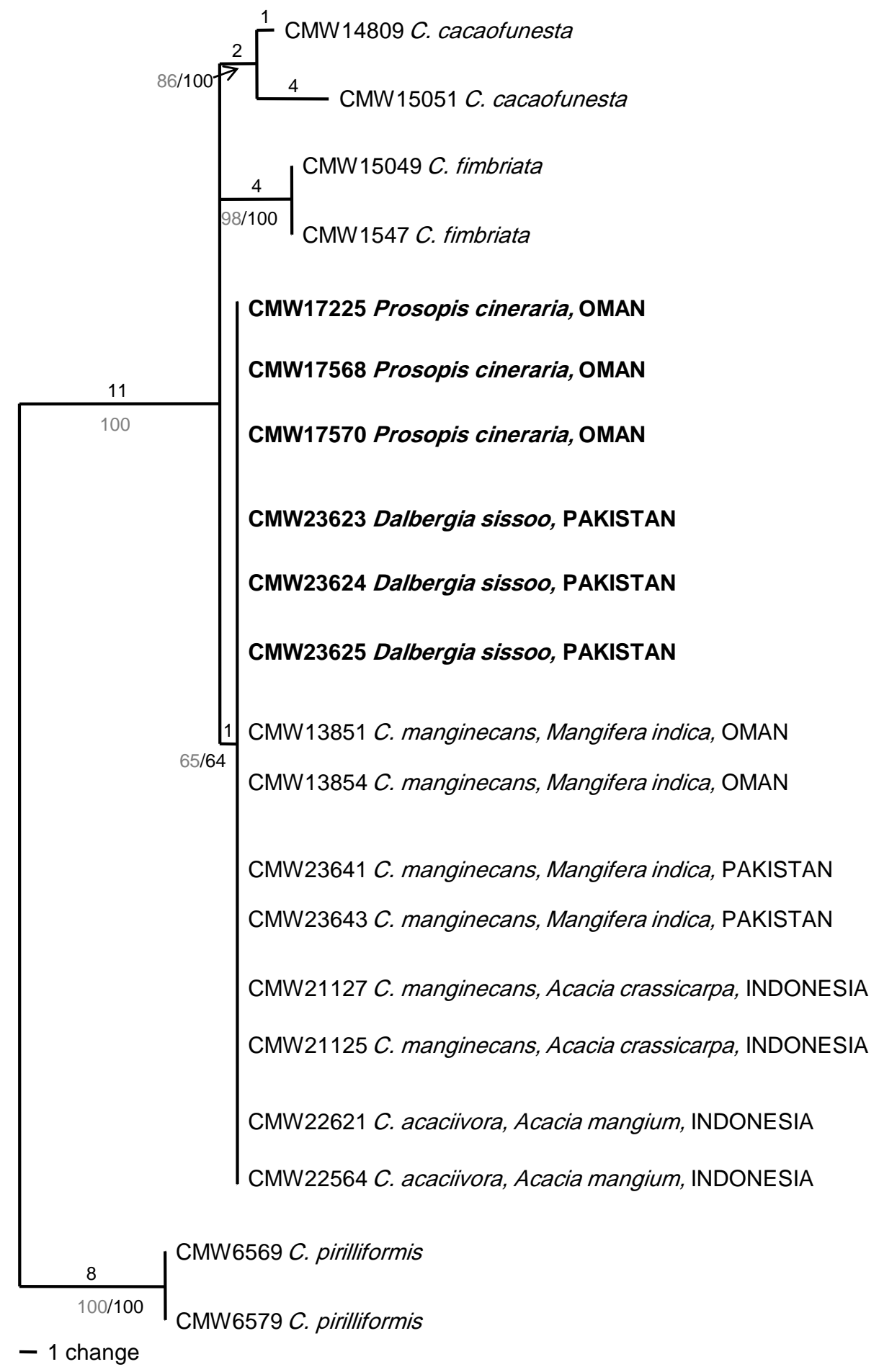




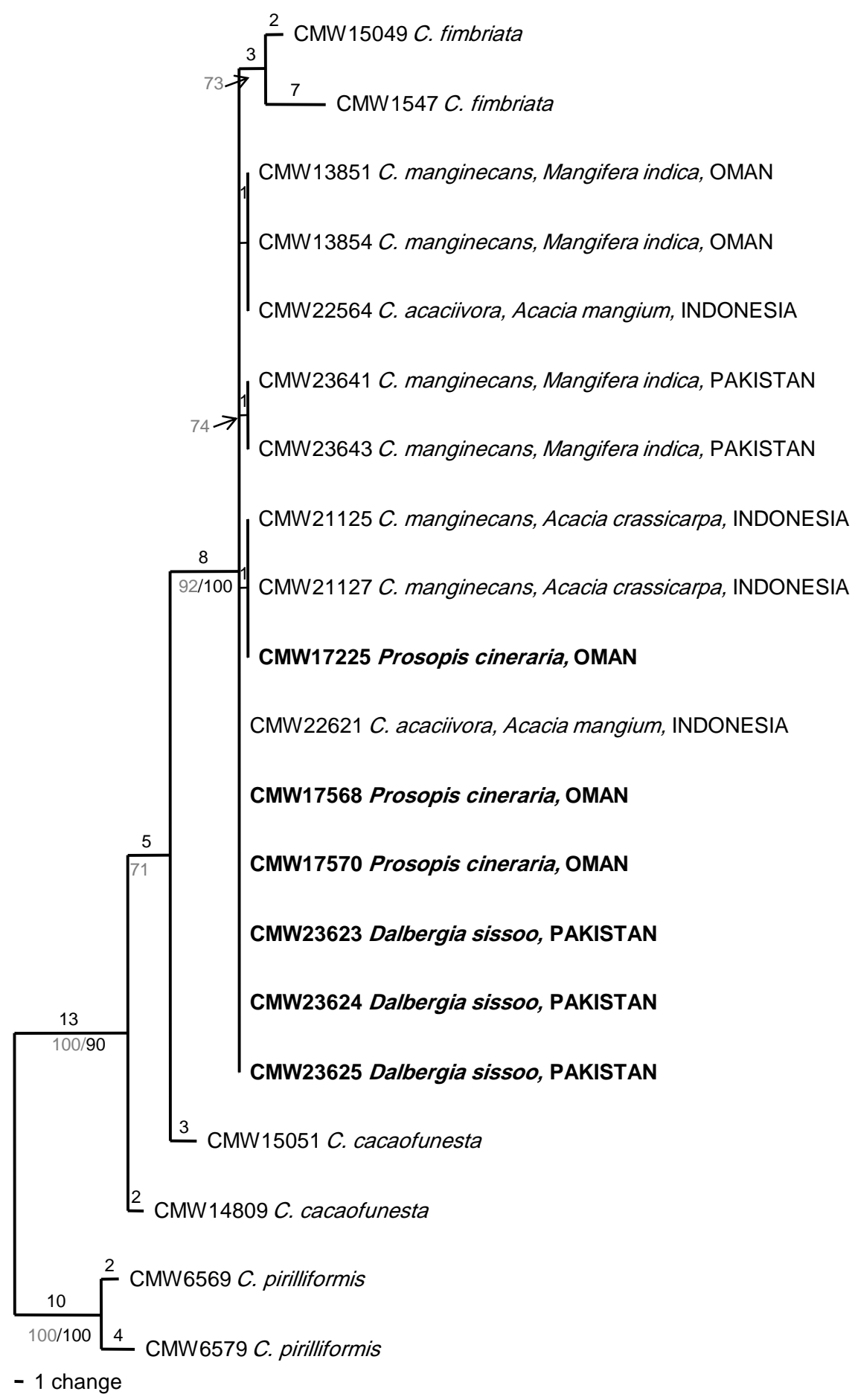

Fig. 2 Maximum parsimony trees resulting from the analysis of sequence data of the (a) ITS (b) $\beta$-tubulin, (c) TEF-1 $\alpha$ gene regions. Bootstrap values and posterior probability values (in bold) are indicated below the branches. Branch lengths are represented above the branches for all trees. Isolates in bold are those sequenced in this study. The isolates reside in two groups in the ITS phylogeny; Group 1 includes $C$. acaciivora isolates and Group 2 includes $C$. manginecans isolates. ITS sequences obtained from isolate CMW17568 fall into both groups showing that this isolate has different ITS types and does not reflect different species. The $\beta$-tubulin and TEF- $1 \alpha$ phylogenies do not differentiate between isolates of C. acaciivora and C. manginecans. 


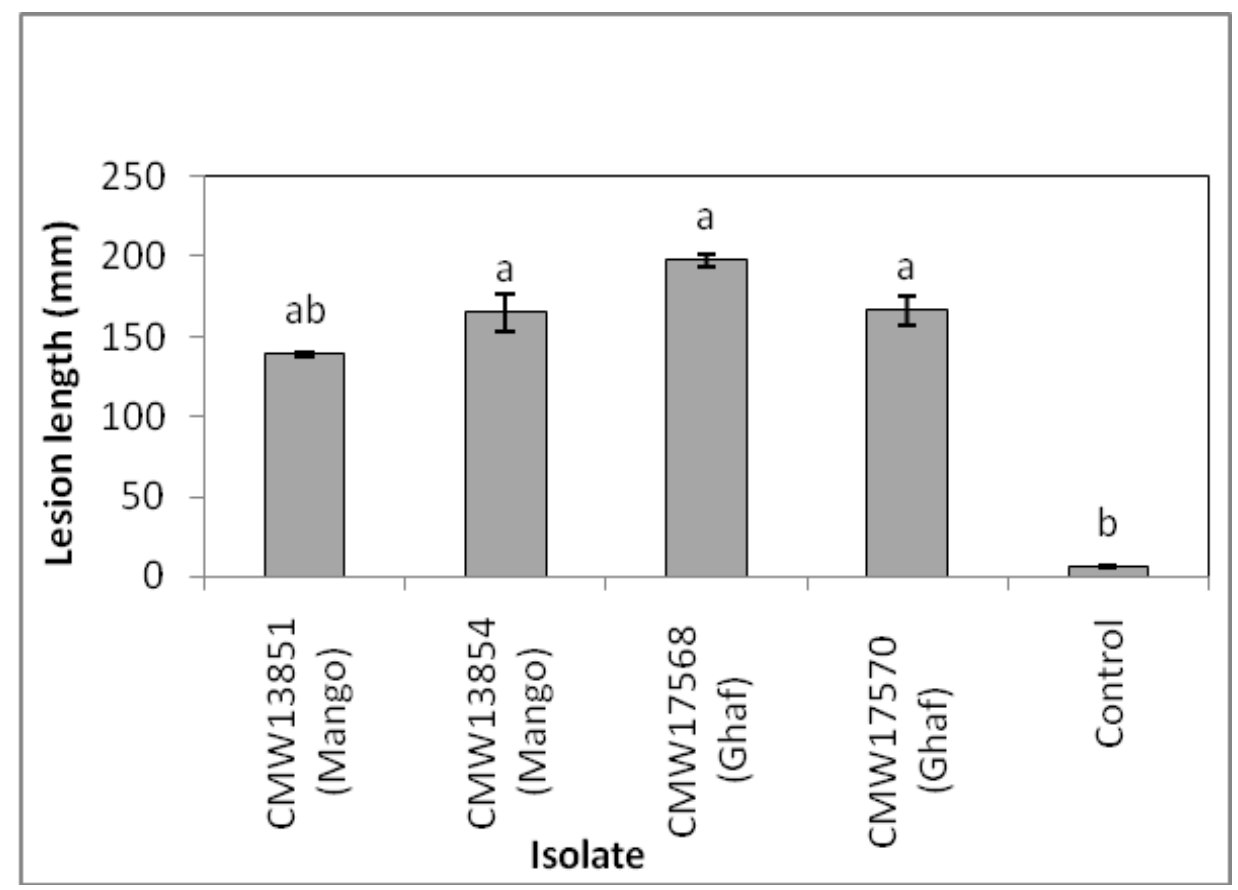

Fig. 3 Lesion lengths arising from inoculations on $P$. cineraria (Ghaf) seedlings using Ceratocystis manginecans isolated from mango (CMW13851 and CMW13854) and Ceratocystis isolates from $P$. cineraria (CMW17568 and CMW17570). Analysis of variance was calculated using a GLM model. Columns represent means of lesion lengths produced by each isolate. Lesion lengths of the isolates marked with same letter were not significantly different from each other at $P<0.05$ using Fisher's (LSD) test. 

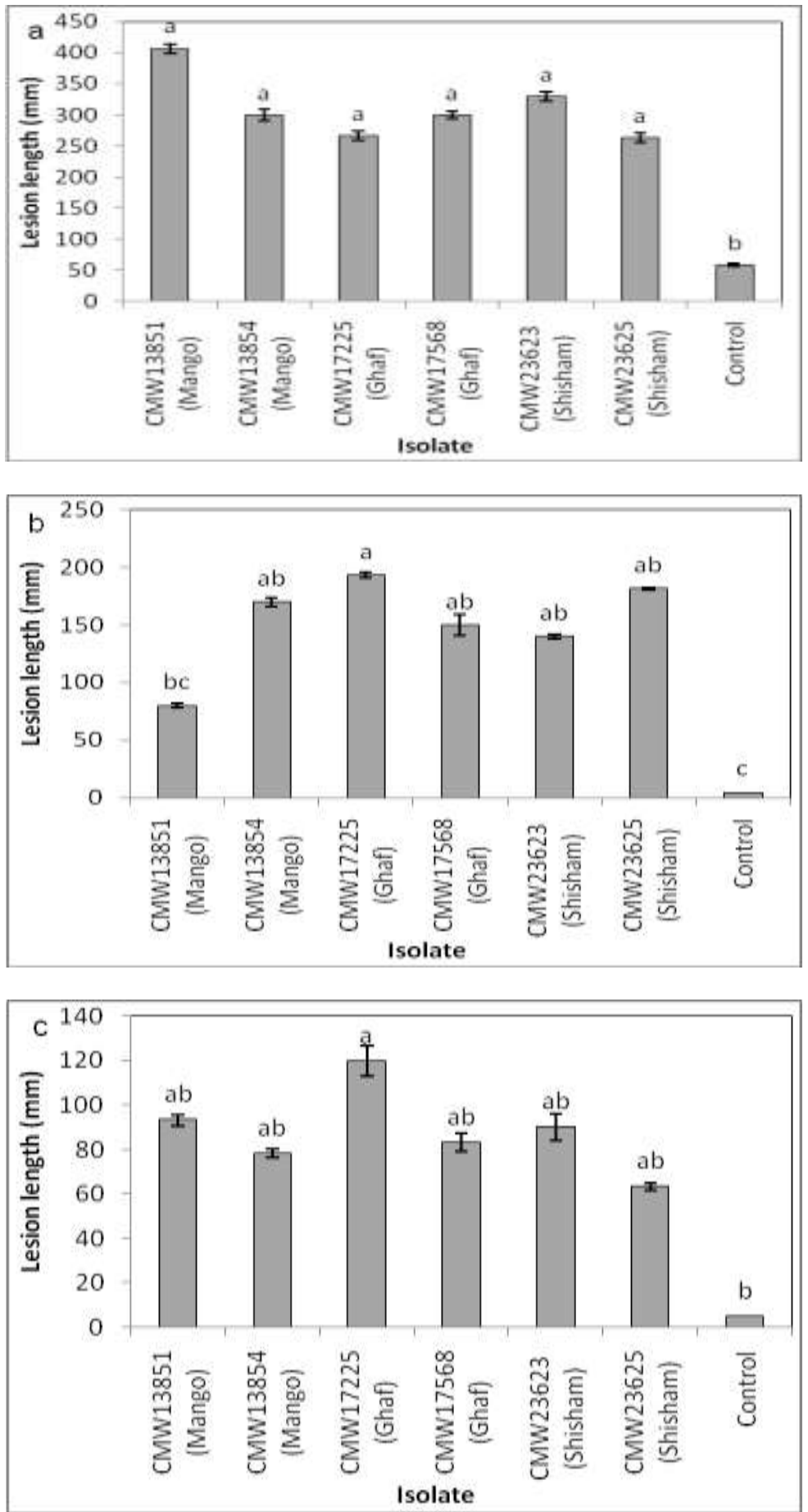

Fig. 4 Cross inoculation experiments on mango (a) P. cineraria (Ghaf) (b) and D. sissoo (Shisham) seedlings (c) using Ceratocystis manginecans isolated from mango (CMW13851 and CMW13854), Ceratocystis isolates from P. cineraria (CMW17225 and CMW17568) and from D. sissoo (CMW23623 and CMW23625). Analysis of variance was calculated using a GLM model. Columns represent means of lesion length for each isolate. Isolates marked with the same letter were not significantly different from each other at $P<0.05$ using Fisher's (LSD) test. 